\title{
Macrophages directed approaches are paramount for effective cancer immunotherapies
}

\author{
Vinod Nadella ${ }^{1}$, Sandhya Singh ${ }^{2}$ and Hridayesh Prakash ${ }^{1 *}$ \\ ${ }^{1}$ Translational Medicine laboratory, School of Life sciences, University of Hyderabad, Telangana, India \\ ${ }^{2}$ Department of Animal Biology, School of Life Sciences, University of Hyderabad, Telangana, India
}

\begin{abstract}
Macrophages are double edge sword component of immunity and display phenotypical and functional plasticity which enable them to both promote and eliminate established tumors. Under the influence of immunosuppressive tumor microenvironment, tumor infiltrating iNOS+ and CD11b+ M-1 regulatory macrophages get polarized to Tumor associated macrophages (TAM) which are Ym-1 and Arginase+ iNOS- (M-2) and tropic to variety of tumors. Increased density of TAM in the variety of tumors has been correlated with poor prognosis which is due to their influence on angiogenesis and tissue re-modelling by which TAM support tumorigenesis as well metastasis. Apart from this, TAMs are also responsible for the maintenance of tumor microenvironment by their virtue of inducing endothelium anergy, which actually represent physical barrier for majority of cancer directed immune / chemotherapies. Therefore functional retuning of TAM to an M-1 phenotype is paramount for effective immunotherapy against established tumors which could be afforded by total body gamma irradiation in neoadjuvant settings or adoptive transfer of iNOS+ macrophages. In this review, we will discuss both existing as well future cancer directed immuno / adjuvant therapies targetting immunosuppresive tumor microenviorment particularly tumor-associated macrophages (TAM) for enhancing immunty against solid tumors (adenocarcinoma).
\end{abstract}

\section{Introduction}

After infections, cancer is next major cause of global morbidity and mortality and poses a significant thread on both patients and their families and the healthcare system as a whole. Available data indicate that the number of cancer-related deaths is more than those caused by AIDS, malaria, and tuberculosis combined; about one in four deaths is due to cancer. A major reason for this high mortality rate lies in resistant nature of variety of tumors against anti-cancer agents and bystander toxicity on healthy tissues and organs [1-4]. Cancer is caused by complex processes, which are directly linked to 'cell division', the fundamental process of life. Unlike normal cells that follow an orderly path of growth, division, and death, cancer cells continue to grow and divide continuously leading to aberrant cell mass which survive programmed death called 'Apoptosis'. According to their origin and location [5] cancers are classified into 200 types with varying degree of resistant against existing anti-cancer drug / therapies. Among various reasons, inefficient $\mathrm{T}$ cell migration is a major limitation [6] of cancer immunotherapy in general. Despite enough advancement was made in this field, none of the therapeutic intervention could prolong the survival of tumor patients beyond few weeks. This is mainly due to symbiotic association of tumor cells and tumor infiltrating macrophages (TAM) which drives sterile inflammatory response during the course of tumorigenesis. Various angiogenesis factors get accumulated at tumor site or within tumor microenvironment which serve as prognostic factors for cancer progression and renders tumor endothelium impermissive for immune cells infiltration. Though, many treatment options have been suggested / made over the past several decades, until today, no single treatment option is promising in controlling solid tumors like pancreatic and lung cancers.

\section{Classical/Traditional treatment options}

Depending on cancer type, tumor size and vasculature, so far three basic and fundamental approaches have been employed for cancer directed therapy and these are surgical resection of tumor, chemotherapy and radiotherapy. As relying on surgery is limited to early stage tumours, treatment options such as chemotherapy and radiotherapy are geared towards killing the cancer cells [7-10] themselves and are currently in use to date. However, these procedures are non-selective and have considerable clinical side effects. The hypoxic or anoxic micro-environment of solid tumour like adenocarcinoma poses a challenge to traditional cancer treatment [11-13] mainly due to increased angiogenesis of tumor. This predisposes tumour cells less susceptible to death by various chemotherapeutic drugs and / or radiotherapy which aimed to increased intratumoral oxygenation for killing by induction of apoptosis. Thus these do not represent good therapeutic options for the treatment of solid tumors cancer.

\section{Alternative/Advanced treatment options}

In recent years, various signalling pathways, which are important / decisive for tumor metabolism and growth, have been targeted by using pharmacological inhibitors for controlling the tumor growth [14]. Many genes like EGFR, p53, TRP53, PTEN, PI-3K XIAP, NF-kb and STAT3 have been identified and targeted [15-17] both chemically / genetically for controlling for rendering tumor cells sensitive for apoptosis. Though, in line with these, various anti-tumor agents and

Correspondence to: Dr. Hridayesh Prakash, Translational Medicine Laboratory, School of Life Sciences, University of Hyderabad, P.O. Central University, Hyderabad 500 046, Telangana, India, Tel: +91-40-66794704, Fax: +91-4023010307/23010120, E-mail: hridayesh.prakash@gmail.com

Key words: macrophages, tumor microenvironment, nanoparticles, radiotherapy, immunotherapy, adenocarcinoma, pancreas

Received: April 05 2016; Accepted: May 02, 2016; Published: May 05, 2016 
strategies were developed, mentioned in table 1 , which extended survival of cancer patients significantly. However, due to genetic and / or epigenetic instability of cancer cells, no single compounds have been successful for breaking the resistance mechanisms to drugs.

\section{Engineered nanoparticles based drug delivery}

With significant advances in chemistry, biotechnology, nanotechnology, pharmacy, medicine, and imaging technologies, focus has been laid over a decade on developing efficient therapeutics that can selectively target the cancerous tissues while distinguishing malignant and benign cells, overcome biological barriers, and respond to the complex heterogeneous microenvironment inside a tumor for on-demand release of therapeutic agents in the optimal dosage range [18-22]. These include nanomedicines, magnetic nano-particles, biopolymers like carbon materials, polymeric systems, and liposomes which are engineered, to meet the expectations of the current needs for effective cancer therapies [23-29]. Delivery of anticancer drugs through a nano-particle-based platform in comparison with traditional chemotherapeutics offers many advantage which include targeted delivery of drugs in a cell or tissues specific manner thus maximizing the treatment efficacy while alleviating systemic side effects, controlled release of drugs over a manageable period of time at precise doses, improved delivery of drugs that are poorly soluble in water, better protection of a drug from harsh environments such as highly acidic environment in the stomach, high levels of proteases or other enzymes in the blood stream before they can reach the targets thus leading to an extended plasma half-life of the drug in the systemic circulation, codelivery of multiple types of drugs for combination therapy $[23,30,31]$.

\section{Antibody-drug conjugates (ADC)}

ADCs are monoclonal antibodies (mAbs) attached to biologically active and highly potent cytotoxic drugs by chemical linkers to specifically bind tumour-associated target antigens [32-34]. The synergistic combination of mAbs conjugated to small-molecule chemotherapeutics, via a stable linker, has given rise to an extremely efficacious class of anti-cancer drugs. This unique combination of three components (mAb, linker and cytotoxin) to target tumor cells help in sensitive discrimination between healthy and diseased tissue while permitting greater control of drug pharmacokinetics. Currently two ADCs have been licensed, T-DM1 targets HER-2 [35,36] and brentuximab vedotin $[37,38]$ and are already established their place in the category of most effective anti cancer drugs while several others are in pipeline.

\section{Photodynamic therapy (PDT)}

PDT, also called as photoradiation therapy or photochemotherapy is a promising alternative approach for improved cancer treatment [39]. A photosensitizer (PS; Porfimer sodium: most widely studied and used)

Table 1. Existing Tumor directed therapies.

\begin{tabular}{|l|c|}
\hline Treatment Type & Reference \\
\hline Engineered Nanoparticle -based drug delivery & {$[23,24]$} \\
\hline Antibody-drug conjugates & {$[23,34,108]$} \\
\hline Immune Check-point Therapy & {$[46]$} \\
\hline Photodynamic Therapy & {$[13,39,109]$} \\
\hline PAMP based Cancer Therapy & {$[55,56,61,64]$} \\
\hline Macrophage-Directed Cancer Immunotherapy & {$[64,65,90,91]$} \\
\hline Stem Cell Transplant & {$[110-112]$} \\
\hline Hyperthermia & {$[113-117]$} \\
\hline Lasers in Cancer Treatment & {$[118,119]$} \\
\hline
\end{tabular}

which gets activated by light of a specific wavelength is administered causing selective damage to the tumor and its surrounding vasculature. The photosensitizing agent is either administered I.V. or S.C allowing the drug to be absorbed by the cancer cells with time. When light is applied to the area to be treated, the light causes the drug to react with oxygen forming a chemical that kills the cells mainly by inducing heat. PDT might also help by destroying the blood vessels that feed the cancer cells and by alerting the immune system to attack the cancer. It is less invasive than surgery, targeted, cost effective with no long-term side effects. PSs can be incorporated in nanostructured drug delivery systems such as liposomes, hydrogels, polymeric nanoparticles (PNP) improves the transcytosis of a PS across epithelial and endothelial barriers and afford the simultaneous co-delivery of two or more drugs. However, the success of PDT is limited mainly due to less invasive potential and their water insolubility.

\section{Immunotherapy}

It is well accepted globally that immune modulation is the prerequisite for the effective therapy of both infections and cancer. This is due to the fact that cancer progression is a result of chronic inflammatory response which has both cellular as well as soluble components which are sufficient to eradicate cancer, if activated properly. Tumor cells driven immune editing or suppression is key factor which tumor cells take advantage off and exploit immune system in their favour. Therefore re-stimulation or readjusting host immune response is certainly believed to offer tremendous therapeutic advantage thus become paramount for effective treatment.

\section{Targeting tumour microenvironment for cancer therapy}

Tumor microenvironment (TME) is best defined as heterogeneous and symbiotic nitch of tumor cells, invaded immune cells (such as Treg, iNK and TAM) blood vessels, non-malignant cells mesenchymal cells and signalling molecules [40]. Other non-malignant cells include stromal cells, fibroblasts, pericytes, adipocytes which secrete growth factors and chemokines which not only promote tumor cells growth but also enhance angiogenesis and chemotaxis of immune cells into the TME [41]. A well-established tumor microenvironment is the result of dynamic equilibrium and symbiotic interactions of these cells [42] which is largely responsible for the development of tumor $[41,43]$. Therefore any tumor directed interventions targeting tumor microenvironment is anticipated to be more effective over other conventional treatment and afford improved clinical outcomes.

\section{Immune check-point therapy}

During malignancy, tumor cells both explore and exploit all possible way to suppress immune response against them because immune cells are the special cells which has the capacity of both eliminating as well as promoting malignancy depending on predominating signals prevailing within TME [44] known as immune check point which dictate immune cells to respond or not to any cellular entity. Out of various such check point listed in Table 2, upregulation of Cytotoxic T lymphocyte-associated antigen 4 (CTLA-4) and programmed cell death protein 1 pathway (PD-1), IDO and A2AR represent one of the best examples which have been well exploited by variety of tumor cells for hijacking host immune response during tumorigenesis [45-49]. Monoclonal antibody therapies directed against CTLA-4 and PD-1/ PD-1L has demonstrated some therapeutic advantage against variety of malignancies. ICOS and SOCS-1 represents another category of 
Table 2. Current status of various immune check point inhibitors based approaches.

\begin{tabular}{|l|l|l|c|}
\hline Potential Target & $\begin{array}{l}\text { Agent (Inhibitory } \\
\text { Receptors) }\end{array}$ & $\begin{array}{l}\text { Stage of clinical } \\
\text { development }\end{array}$ & References \\
\hline CTLA-4 & $\begin{array}{l}\text { Ipilimumab } \\
\text { Tremelimumab }\end{array}$ & $\begin{array}{l}\text { Phase I/II/III/IV } \\
\text { Phase I/II/III }\end{array}$ & {$[48,49,120]$} \\
\hline PD-1 & $\begin{array}{l}\text { Nivolumab (MDX1106) } \\
\text { Lembrolizumab (MK3475) } \\
\text { Lambrolizumab } \\
\text { Pidilizumab (CT-011) } \\
\text { AMP-514 (MEDI0680; } \\
\text { anti-PD-1) }\end{array}$ & $\begin{array}{l}\text { Phase I/II/III/IV } \\
\text { Phase I/II } \\
\text { Phase I,II }\end{array}$ & {$[46,121-124]$} \\
\hline PD-L1 & $\begin{array}{l}\text { BMS935559(MDX1105) } \\
\text { MPDL3280A } \\
\text { MEDI4736 } \\
\text { MSB0010718C }\end{array}$ & $\begin{array}{l}\text { Phase I } \\
\text { Phase I } \\
\text { Phase I } \\
\text { Phase I }\end{array}$ & {$[125-129]$} \\
\hline IDO & $\begin{array}{l}\text { D-1MT } \\
\text { INCB024360 }\end{array}$ & $\begin{array}{l}\text { Phase II } \\
\text { Phase II }\end{array}$ & {$[130-133]$} \\
\hline A2AR & SCH58261, SYN115 & Phase I/II & {$[134-137]$} \\
\hline TIM-3 & Anti-TIMP3 & Pre-clinical & {$[138-140]$} \\
\hline LAG3 & IMP321 & Phase I/II/ III & {$[141,142]$} \\
\hline KIR & $\begin{array}{l}\text { Lirilumab (IPH2101) } \\
\text { Nivolumab }\end{array}$ & $\begin{array}{l}\text { Phase I/II } \\
\text { Phase I }\end{array}$ & {$[143,144]$} \\
\hline
\end{tabular}

immune check points which negatively regulate TNF mediated tumor killing and support the developed of tolerogenic immune cells [50,51].

\section{PAMP based cancer therapy}

In both mouse and human tumor models, systemic activation of tissue-resident macrophages in vivo by either TLR ligands (mainly bacterial product) or CD40 stimulation [52-54] have been tried for effective anti-tumor immune response which is attributed to functional retuning of M2 TAM to M1 macrophages by such therapeutic interventions. Thus, such retuning may be paramount for effective cancer therapy in general and of cancer immunotherapy in particular. Several strains of bacteria like Clostridium spp. have capacity to selectively colonize in the hypoxic and necrotic areas of the tumour microenvironment [55-57] causing significant oncolysis. With the advent of biotechnology and bio-engineering, various strategies utilizing Clostridium are currently being investigated, enabling the delivery of therapeutics directly to the tumour in situ. In those lines, Clostridium-directed Antibody therapy (CDTA) where Clostridium is engineered to produce highly specific antibodies against tumour antigens is under use. One such approach was targeting HIF1 $\alpha$ in tumour cells to control hypoxia and factors contributing to metastasis and invasion [58-61]. Another novel treatment option available is engineering $C$. acetobutylicum to express enzyme such as TNF- $\alpha$ that possess direct cytotoxic actions, as opposed to having pro-drug cleaving actions. The main mechanism by which bacterial derived product has shown promises against tumor cells is by their virtue of enhancing the release of TNF- $\alpha$ that is strongly anti tumor in nature, if produced in high doses where it functions as a vasculo-toxic agent [62]. Additionally, bacterial can be genetically engineered for multi enzyme effect that results in the release of tumour antigens from cells that have become necrotic, thus increasing the anti-tumour response by immune cells $[63,64]$. However, systemic activation of innate immune cells through bacterial product, sometime manifest severe systemic side effects limiting their use as safe option for clinical intervention.

\section{Macrophage-directed cancer immunotherapy}

Among various cells of immune system, like macrophages, neutrophiles, dendrites cells and natural killer cells, macrophages are double edged component and bear potential of both promoting cancer progression as well as rejection depending upon their phenotype they display. Macrophages are well known and integrated part of both innate and cellular immunity. Both peripheral and tissue macrophages together constitute the Reticulo-endothelium system which play major role in guiding tumor antigens for their establishment and metastasis as well as their effective eradication [65]. The presence of TAM at the tumor site represents one of the hallmarks of cancer-associated inflammation $[66,67]$. Normally tumors are infiltrated with leukocytes and their cross-talk with neoplastic tissues has shown profound effects on tumor progression or regression [65,68]. Phenotypic imbalance in M1/M2 effector phenotype during tumorigenesis is one of the major etiological factors which promote tumor growth by various mechanisms. For this point of view, M1 effector phenotype of macrophage thus represent the most suitable target cell populations for rendering tumor directed therapeutic interventions more effective. Histo-pathological analysis of several tumors revealed that around $50 \%$ of the tumor mass is composed of leukocyte among which T-lymphocytes and macrophages represent the major proportion [69-71]. The presence of these T cells within human tumors has been considered as an evidence of host immunity against tumor [72,73]. T lymphocytes have been found associated with a more favourable clinical outcome in colorectal, ovarian cancer, and melanoma. In contrast to T cells, macrophages is very well correlated in most - though not all tumors with increased tumor angiogenesis, invasion, poor prognosis as well as several function of regulatory $\mathrm{T}$ cells [74-76]. Recent reports have demonstrated that various cytokines that are released from macrophages have tropic influence on tumors for their progression and metastasis [77-79]. The most pro-vital role of tumor associated macrophages by which they regulate the tumor micro-environment is to their potential to secrete plethora of cytokines/growth factors like VEGF- $\beta$, low concentrations of TNF- $\alpha$, TGF- $\beta$, and Hypoxia Inducible Factor $[65,80-84]$. These secretions are most essential for the integrity of tumor microenvironment [85-89]. Therefore modulating the cytokine network between these tropical tumor associated macrophages and tumor cells could limit tumor progression would be the most effective immuno-therapy of the established and chronic tumor. Macrophages recruited into tissue react to variety of inflammatory and immune stimuli and attain differential phenotypes namely classically activated (M1), or alternatively activated (M2) macrophages as shown in Figure 1 , thus reflecting the signals from the microenvironment they dwell in $[90,91]$. Classically activated macrophages are immunostimulatory with Th1-orienting properties while M2 are immunoregulatory with Th2 immune response [92]. Tumor polarized macrophages are referred as tumor-associated macrophage (TAM) $[93,94]$, which exhibits several pro-tumoral functions, mentioned above [90,95]. TAM accumulation in majority of tumours and subsequent phenomenal changes being a major hurdle resulting in poor cancer prognosis, macrophage depletion, e.g. seems to one good therapeutic alternatives macrophage depletion using KO mouse (LySM cre, op/op mouse model) approaches or use of pharmacological drugs such as clodronate liposomes have shown to reduce tumor progression [96] \& our unpublished data). Sessa et al have shown Trabectedin, a natural product derived from marine organism Ecteinascidia turbinate being specifically toxic to macrophages by affecting NF-Y, and KLF-2/4 transcription factors of major importance for mononuclear phagocyte differentiation thus other lymphocyte subsets in TME $[97,98]$. In similar lines, targeting TAM by acting on molecular pathways for TAM polarization such as NF- $\kappa \mathrm{B}$, STAT3 and HIF-1 which are considered to be the master regulators of TAM transcriptional programmes represent another potential therapeutic option. We have recently shown the therapeutic 
Stimulation: LPS, TNF $\alpha$, IFN $\gamma$

Expression: MHC II, iNOS, IL-1 $\beta$,

CD38, CD80, CD86, TLR2, TLR4

Cytokines: IL-6, IL-12, IL23

Chemokines: CXCL9, CXCL10,

CXCL11

Signalling: STAT1, NOS2, SOCS3

Functions

Pro-inflammatory

Immune stimulation

Tumor Suppression

Tissue injury

Th1 programming
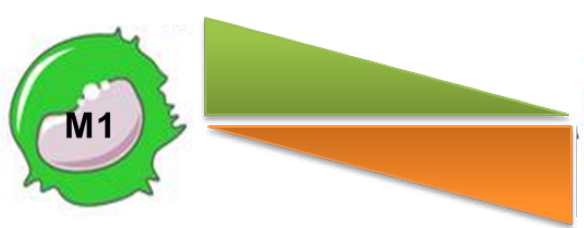

Stimulation: IL4, IL13

Expression: MHC II, CD163, CD206, CD80, CD83, CD86, TG2,

(Mouse only: Arg-1, Ym-1, Fizz1)

Cytokines: IL-10, TGF $\beta$

Chemokines: CXCL17, CXCL18,

CXCL22

Signalling: STAT3, STAT6, SOCS1

\section{Functions}

Anti-inflammatory

Immune Regulation

Tumor Promotion

Matrix deposition

Tissue repair and remodeling

Scavenging

Th2/Th17 programming

Figure 1. Schematic representation of phenotypic as well functional plasticity of macrophages. Macrophages are the special cells of host immune system, which, by their virtue of phenotypic plasticity can both control as well promote tumor growth thus represent key therapeutic target of current and future cancer immunotherapeutic interventions.
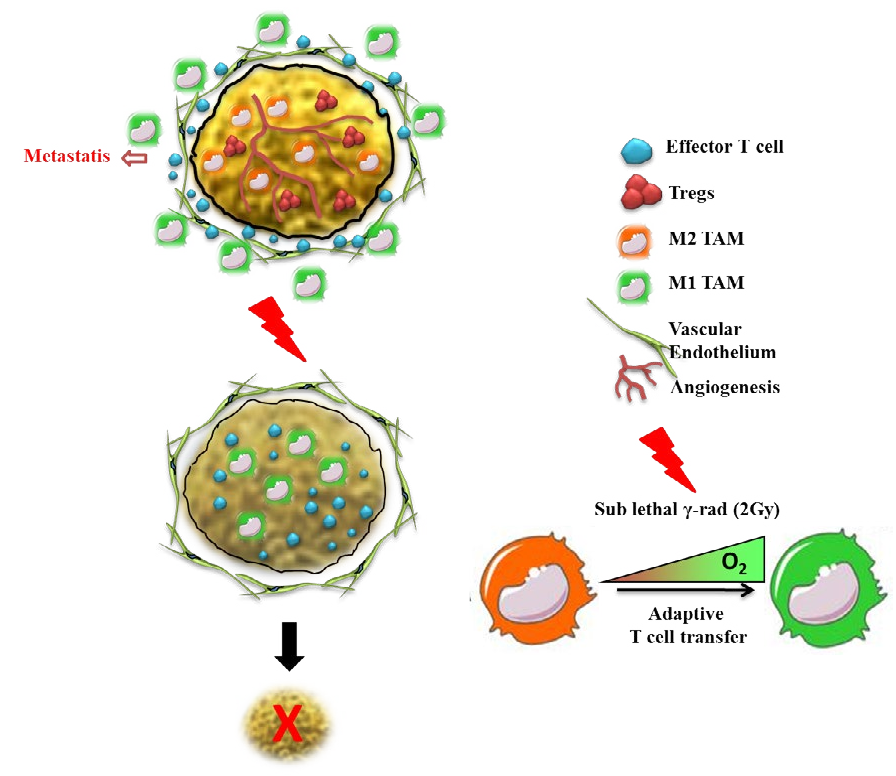

Figure 2. Tumor targeting by Low dose Radiotherapy. Low does radiotherapy potentially target tumor microenvironment mainly by functional retuning of TAM and unlocking endothelium anergy and support $\mathrm{T}$ cell based therapy for inducing tumor immune rejection of established tumor of pancreas and melanoma in therapeutic setting.

impact of low doses of gamma irradiation (LDI) in neo adjuvant setting as a potential non-invasive approach to improve cancer immunotherapy (a new feather in the traditional radiation therapy). Taking advantage of the fact that low dose of ionizing radiation activate immune cells including macrophages in vivo [99-103], we have recently shown that the potential impact of therapeutic radiation in skewing M1 repolarization of M2 subsets of macrophages within established tumours of pancreas $[90,91]$ and demonstrated that LDI had an impact on tuning TAM M2 to M1 phenotype thus aiding in tumor directed T cell infiltration and subsequent tumour rejection in neuro-endocrine pancreatic tumour mice model (Figure 2). In similar lines, systemic irradiation also contributed for normalising tumor vasculature in a macrophage dependent manner [90]. Interestingly, single adoptive transfer of macrophages from systemically irradiated mice with LDI also resulted in enhanced cellular immunity in tumor bearing recipient mice in the absence of external radiation suggesting that systemic radiation with LDI is vital for macrophage retuning from M2 to M1 which is the current need of tumor directed therapies.

\section{Mesenchymal cell therapy}

Successful therapy against infection or tumor, should in principle, normalize tumor vasculature and overcome treatment related toxicities. To this end, tissue regeneration or homeostasis is critical for bringing body or tissue back to normal physiological status. This could be achieved by both subsiding inflammatory response and / or inducing cellular proliferation for replenishing tissue mass which is normally lost during various therapeutic regimens. MSC -based regenerative therapies have been introduced recently which function on their ability to differentiate into different mesenchymal lineages and to function as immunomodulatory / suppressive, angiogenic, antiapoptotic, and proliferative agents [104,105]. Like TAM, MSC also secrete various factors which are involved in wound healing (VEGF, HGF etc.) as well as in immune suppression (PEG2, IDO) [106,107] and correlate with cancer progression, development, recurrence and metastasis. MSC has been instrumental in promoting cancer stem cell function or promoting tumor associated macrophages (TAM) function in tumor microenvironment. Therefore, an efficient strategy would be to engineer a different cell such as dermal fibroblast to promote MSClike "immuno-privilege" devoid of associated secretory profile of the MSC for tissue regeneration post therapy.

\section{Conclusion and future perspectives}

These studies potentially demonstrate the significance of macrophage directed therapies in controlling tumor burden. On the basis of this, it is believed that changing of macrophages phenotype may improve or escort current tumor directed interventions which are facing therapeutic challenges in clinics. Management of M1/M2 
imbalance is also believed to key also to minimize the risk of having cancer by chronic and persistent infection with intracellular pathogens like Chlamydia sp., Mycobacteria sp., H. pylori and others which, like tumor, also exploit Macrophage polarization for cancer development.

\section{Acknowledgements}

This work was supported by Ramanujan research grant to H.P. from Sciences and Engineering Research Board, DST. VN is supported by funding from Defense Research and Development organization, Govt of India, S.S. is the recipient of Ramanujan fellowship DST-young Scientist fellowship. HP is the recipient of from DST, Govt of India.

\section{References}

1. Yang J, Huang X, Luo F, Cheng X, Cheng L, et al. (2014) Preparation and functional studies of hydroxyethyl chitosan nanoparticles loaded with anti-human death receptor 5 single-chain antibody. Onco Targets Ther 7: 779-787. [Crossref]

2. Guan M, Zhou Y, Zhu QL, Liu Y, Bei YY, et al. (2012) N-trimethyl chitosan nanoparticle-encapsulated lactosyl-norcantharidin for liver cancer therapy with high targeting efficacy. Nanomedicine 8: 1172-1181. [Crossref]

3. Arya G, Vandana M, Acharya S, Sahoo SK (2011) Enhanced antiproliferative activity of Herceptin (HER2)-conjugated gemcitabine-loaded chitosan nanoparticle in pancreatic cancer therapy. Nanomedicine 7: 859-870. [Crossref]

4. Tan ML, Choong PF, Dass CR (2009) Cancer, chitosan nanoparticles and catalytic nucleic acids. J Pharm Pharmacol 61: 3-12. [Crossref]

5. Idikio HA (2011) Human cancer classification: a systems biology- based mode integrating morphology, cancer stem cells, proteomics, and genomics. J Cancer 2: 107115. [Crossref]

6. Idikio HA (2011) Galectin-3 and Beclin1/Atg6 genes in human cancers: using cDNA tissue panel, qRT-PCR, and logistic regression model to identify cancer cell biomarkers. PLoS One 6: e26150. [Crossref]

7. Wissing MD (2015) Chemotherapy- and irradiation-induced bone loss in adults with solid tumors. Curr Osteoporos Rep 13: 140-145. [Crossref]

8. Cotter SE, McBride SM, Yock TI (2012) Proton radiotherapy for solid tumors of childhood. Technol Cancer Res Treat 11: 267-278. [Crossref]

9. Huang CY, Pourgholami MH, Allen BJ (2012) Optimizing radioimmunoconjugate delivery in the treatment of solid tumor. Cancer Treat Rev 38: 854-860. [Crossref]

10. Govindan SV, Goldenberg DM (2010) New antibody conjugates in cancer therapy. Scientific World Journal 10: 2070-2089. [Crossref]

11. Yang Y, Sun M, Wang L, Jiao B (2013) HIFs, angiogenesis, and cancer. J Cell Biochem 114: 967-974. [Crossref]

12. Harada H, Kizaka-Kondoh S, Li G, Itasaka S, Shibuya K, et al. (2007) Significance of HIF-1-active cells in angiogenesis and radioresistance. Oncogene 26: 7508-7516. [Crossref]

13. Brown JM, Siim BG (1996) Hypoxia-Specific Cytotoxins in Cancer Therapy. Semin Radiat Oncol 6: 22-36. [Crossref]

14. Hanahan D, Weinberg RA (2011) Hallmarks of cancer: the next generation. Cell 144: 646-674. [Crossref]

15. Pere H, Montier Y, Bayry J, Quintin-Colonna F, Merillon N, et al. (2011) A CCR4 antagonist combined with vaccines induces antigen-specific CD8+ T cells and tumor immunity against self antigens. Blood 118: 4853-4862. [Crossref]

16. Falcon BL, Pietras K, Chou J, Chen D, Sennino B, et al. (2011) Increased vascular delivery and efficacy of chemotherapy after inhibition of platelet-derived growth factor-B. Am J Pathol 178: 2920-2930. [Crossref]

17. Allen E, Walters IB, Hanahan D (2011) Brivanib, a dual FGF/VEGF inhibitor, is active both first and second line against mouse pancreatic neuroendocrine tumors developing adaptive/evasive resistance to VEGF inhibition. Clin Cancer Res. 17: 5299-5310. [Crossref]

18. Lim K, Erickson B, Jürgenliemk-Schulz IM, Gaffney D, Creutzberg CL, et al. (2015) Variability in clinical target volume delineation for intensity modulated radiation therapy in 3 challenging cervix cancer scenarios. Pract Radiat Oncol 5: e557-e565. [Crossref]
19. Lim SH, Chua W, Henderson C, Ng W, Shin JS, et al. (2015) Predictive and prognostic biomarkers for neoadjuvant chemoradiotherapy in locally advanced rectal cancer. Crit Rev Oncol Hematol 96: 67-80.

20. Jokerst JV, Lobovkina T, Zare RN, Gambhir SS (2011) Nanoparticle PEGylation for imaging and therapy. Nanomedicine (Lond) 6: 715-728. [Crossref]

21. Jokerst JV, Miao Z, Zavaleta C, Cheng Z, Gambhir SS (2011) Affibody-functionalized gold-silica nanoparticles for Raman molecular imaging of the epidermal growth factor receptor. Small 7: 625-633. [Crossref]

22. Peer FI, Pui MH, Mosam A, Rae WI (2007) 99mTc-MIBI imaging of cutaneous AIDSassociated Kaposi's sarcoma. Int J Dermatol 46: 166-171. [Crossref]

23. Amgoth C, Dharmapuri G, Kalle AM, Paik P (2016) Nanoporous capsules of block co-polymers of [(MeO-PEG-NH)-b-(L-GluA)]-PCL for the controlled release of anticancer drugs for therapeutic applications. Nanotechnology 27: 125101. [Crossref]

24. Kumar A, Singh UK, Chaudhary A (2015) Targeting autophagy to overcome drug resistance in cancer therapy. Future Med Chem 7: 1535-1542. [Crossref]

25. Kumar CG, Poornachandra Y, Chandrasekhar C (2015) Green synthesis of bacteria mediated anti-proliferative gold nanoparticles: inducing mitotic arrest (G2/M phase) and apoptosis (intrinsic pathway). Nanoscale 7: 18738-18750. [Crossref]

26. Kumar R, Shin WS, Sunwoo K, Kim WY, Koo S, et al. (2015) Small conjugate-based theranostic agents: an encouraging approach for cancer therapy. Chem Soc Rev 44: 6670-6683. [Crossref]

27. Kumar R, Chauhan JS, Raghava GP1 (2015) In Silico Designing and Screening of Antagonists against Cancer Drug Target XIAP. Curr Cancer Drug Targets 15: 836846. [Crossref]

28. YuZ, Sun Q, Pan W, LiN, Tang B (2015) A Near-Infrared Triggered Nanophotosensitize Inducing Domino Effect on Mitochondrial Reactive Oxygen Species Burst for Cancer Therapy. ACS Nano 9: 11064-11074. [Crossref]

29. Yu S, Cao H, Shen B, Feng J (2015) Tumor-derived exosomes in cancer progression and treatment failure. Oncotarget 6: 37151-37168. [Crossref]

30. Perrie Y, Crofts F, Devitt A, Griffiths HR, Kastner E, et al. (2016) Designing liposoma adjuvants for the next generation of vaccines. Adv Drug Deliv Rev 99: 85-96. [Crossref]

31. Babu K, Mahendradas P (2013) Medical management of uveitis - current trends. Indian J Ophthalmol 61: 277-283. [Crossref]

32. Peters C, Brown S (2015) Antibody-drug conjugates as novel anti-cance chemotherapeutics. Biosci Rep 35. [Crossref]

33. Panowksi S, Bhakta S, Raab H, Polakis P, Junutula JR (2014) Site-specific antibody drug conjugates for cancer therapy. MAbs 6: 34-45. [Crossref]

34. Shah DK, Haddish-Berhane N, Betts A (2012) Bench to bedside translation of antibody drug conjugates using a multiscale mechanistic PK/PD model: a case study with brentuximab-vedotin. J Pharmacokinet Pharmacodyn 39: 643-659. [Crossref]

35. Haddley K (2013) Trastuzumab emtansine for the treatment of HER2-positive metastatic breast cancer. Drugs Today (Barc) 49: 701-715. [Crossref]

36. Harbeck N, Wuerstlein R (2013) Optimal sequencing of anti-HER2 therapy throughout the continuum of HER2-positive breast cancer: evidence and clinical considerations. Drugs 73: 1665-1680. [Crossref]

37. Canellos GP (2012) Brentuximab vedotin and panobinostat: new drugs for Hodgkin's lymphoma--can they make one of medical oncology's chemotherapy success stories more successful? J Clin Oncol 30: 2171-2172. [Crossref]

38. Sievers EL, Senter PD (2013) Antibody-drug conjugates in cancer therapy. Annu Rev Med 64: 15-29. [Crossref]

39. Calixto GM, Bernegossi J, de Freitas LM, Fontana CR, Chorilli M (2016) Nanotechnology-Based Drug Delivery Systems for Photodynamic Therapy of Cancer: A Review. Molecules 21. [Crossref]

40. Quail DF, Joyce JA (2013) Microenvironmental regulation of tumor progression and metastasis. Nat Med 19: 1423-1437. [Crossref]

41. Hanahan D, Coussens LM (2012) Accessories to the crime: functions of cells recruited to the tumor microenvironment. Cancer Cell 21: 309-322. [Crossref]

42. Balkwill FR (2012) The chemokine system and cancer. J Pathol 226: 148-157. [Crossref]

43. Fidler DP (2003) Emerging trends in international law concerning global infectious disease control. Emerg Infect Dis 9: 285-290. [Crossref] 
44. Zamarron BF, Chen W (2011) Dual roles of immune cells and their factors in cancer development and progression. Int J Biol Sci 7: 651-658. [Crossref]

45. Callahan MK, Postow MA, Wolchok JD (2013) Immunomodulatory therapy for melanoma: ipilimumab and beyond. Clin Dermatol 31: 191-199. [Crossref]

46. Topalian SL, Hodi FS, Brahmer JR, Gettinger SN, Smith DC, et al. (2012) Safety, activity, and immune correlates of anti-PD-1 antibody in cancer. $N$ Engl J Med 366: 2443-2454. [Crossref]

47. Pardoll DM1 (2012) The blockade of immune checkpoints in cancer immunotherapy. Nat Rev Cancer 12: 252-264. [Crossref]

48. Robert NJ, Diéras V, Glaspy J, Brufsky AM, Bondarenko I, et al. (2011) RIBBON-1: randomized, double-blind, placebo-controlled, phase III trial of chemotherapy with or without bevacizumab for first-line treatment of human epidermal growth factor receptor 2-negative, locally recurrent or metastatic breast cancer. J Clin Oncol 29: 1252-1260. [Crossref]

49. Hodi FS (2010) Overcoming immunological tolerance to melanoma: Targeting CTLA4. Asia Pac J Clin Oncol 6: S16-23. [Crossref]

50. Greenwald RJ, Freeman GJ, Sharpe AH (2005) The B7 family revisited. Annu Rev Immunol 23: 515-548. [Crossref]

51. Yoshimura A, Suzuki M, Sakaguchi R, Hanada T, Yasukawa H (2012) SOCS, Inflammation, and Autoimmunity. Front Immunol 3: 20. [Crossref]

52. Beatty GL, Chiorean EG, Fishman MP, Saboury B, Teitelbaum UR, et al. (2011) CD40 agonists alter tumor stroma and show efficacy against pancreatic carcinoma in mice and humans. Science 331: 1612-1616. [Crossref]

53. Schmidt J, Jäger D, Hoffmann K, Büchler MW, Märten A (2007) Impact of interferonalpha in combined chemoradioimmunotherapy for pancreatic adenocarcinoma (CapRI): first data from the immunomonitoring. J Immunother 30: 108-115. [Crossref]

54. Huang Z, Zhang Z, Jiang Y, Zhang D, Chen J, et al. (2012) Targeted delivery of oligonucleotides into tumor-associated macrophages for cancer immunotherapy. $J$ Control Release 158: 286-292. [Crossref]

55. Kubiak AM, Minton NP (2015) The potential of clostridial spores as therapeutic delivery vehicles in tumour therapy. Res Microbiol 166: 244-254. [Crossref]

56. Umer B, Good D, Anné J, Duan W, Wei MQ (2012) Clostridial spores for cancer therapy: targeting solid tumour microenvironment. J Toxicol 2012: 862764. [Crossref]

57. Lambin P, Ahaded A, Debbia M, Lauroua P, Rouger P (1998) An enzyme-linked immunosorbent assay for the quantitation of $\operatorname{IgG}$ anti-D and $\mathrm{IgG}$ subclasses in the sera of alloimmunized patients. Transfusion 38: 252-261. [Crossref]

58. Gort EH, Groot AJ, Derks van de Ven TL, van der Groep P, Verlaan I, et al. (2006) Hypoxia-inducible factor-1 alpha expression requires PI 3-kinase activity and correlates with Akt1 phosphorylation in invasive breast carcinomas. Oncogene 25: 6123-6127. [Crossref]

59. de Groot, J. W., T. P. Links, J. T. Plukker, C. J. Lips, and R. M. Hofstra. (2006) RET as a diagnostic and therapeutic target in sporadic and hereditary endocrine tumors. Endocr Rev 27: 535-560. [Crossref]

60. de Groot JF, Gilbert MR (2007) New molecular targets in malignant gliomas. Curr Opin Neurol 20: 712-718. [Crossref]

61. Groot AJ, Mengesha A, van der Wall E, van Diest PJ, Theys J, et al. (2007) Functional antibodies produced by oncolytic clostridia. Biochem Biophys Res Commun 364: 985989. [Crossref]

62. Theys J, Nuyts S, Landuyt W, Van Mellaert L, Dillen C, et al. (1999) Stable Escherichia coli-Clostridium acetobutylicum shuttle vector for secretion of murine tumor ecrosis factor alpha. Appl Environ Microbiol 65: 4295-4300. [Crossref]

63. Brunet AS, Ploton C, Galambrun C, Pondarré C, Pages MP, et al. (2006) Low incidence of sepsis due to viridans streptococci in a ten-year retrospective study of pediatric acute myeloid leukemia. Pediatr Blood Cancer 47: 765-772. [Crossref]

64. Barbé S, Van Mellaert L, Theys J, Geukens N, Lammertyn E, et al. (2005) Secretory production of biologically active rat interleukin-2 by Clostridium acetobutylicum DSM792 as a tool for anti-tumor treatment. FEMS Microbiol Lett 246: 67-73. [Crossref]

65. Saio M, Radoja S, Marino M, Frey AB (2001) Tumor-infiltrating macrophages induce apoptosis in activated $\mathrm{CD} 8(+) \mathrm{T}$ cells by a mechanism requiring cell contact and mediated by both the cell-associated form of TNF and nitric oxide. J Immunol 167 : 5583-5593. [Crossref]

66. Lin EY, Pollard JW (2004) Macrophages: modulators of breast cancer progression. Novartis Found Symp 256: 158-168. [Crossref]
67. Pollard JW (2004) Tumour-educated macrophages promote tumour progression and metastasis. Nat Rev Cancer 4: 71-78. [Crossref]

68. Kryczek I, Zou L, Rodriguez P, Zhu G, Wei S, et al. (2006) B7-H4 expression identifies a novel suppressive macrophage population in human ovarian carcinoma. $J$ Exp Med 203: 871-881. [Crossref]

69. Yusuf N, Katiyar SK, Elmets CA (2008) The immunosuppressive effects of phthalocyanine photodynamic therapy in mice are mediated by CD4+ and CD8+ T cells and can be adoptively transferred to naive recipients. Photochem Photobiol 84: 366-370. [Crossref]

70. Mattes J, Hulett M, Xie W, Hogan S, Rothenberg ME, et al. (2003) Immunotherapy of cytotoxic T cell-resistant tumors by Thelper 2 cells: an eotaxin and STAT6-dependent process. J Exp Med 197: 387-393. [Crossref]

71. Mukai S, Kagamu H, Shu S, Plautz GE (1999) Critical role of CD11a (LFA-1) in therapeutic efficacy of systemically transferred antitumor effector T cells. Cell Immunol 192: 122-132. [Crossref]

72. Mason K, Staab A, Hunter N, McBride W, Petersen S, et al. (2001) Enhancement of tumor radioresponse by docetaxel: Involvement of immune system. Int J Oncol 18 599-606. [Crossref]

73. Makidono R (1996) [A mechanism involved in augmentation of anti-tumor immunity by irradiation to the tumor: tumor irradiation promoted generation of $\mathrm{CD} 4+$ helper $\mathrm{T}$ cells against a murine immunogenic tumor]. Nippon Igaku Hoshasen Gakkai Zasshi 56: 575-578. [Crossref]

74. Chesney J, Metz C, Bacher M, Peng T, Meinhardt A, et al. (1999) An essential role for macrophage migration inhibitory factor (MIF) in angiogenesis and the growth of a murine lymphoma. Mol Med 5: 181-191. [Crossref]

75. Riemann D, Kehlen A, Thiele K, Löhn M, Langner J (1997) Induction of aminopeptidase $\mathrm{N} / \mathrm{CD} 13$ on human lymphocytes after adhesion to fibroblast-like synoviocytes, endothelial cells, epithelial cells, and monocytes/macrophages. J Immunol 158: 3425 3432. [Crossref]

76. Hartung HP (1993) Immune-mediated demyelination. Ann Neurol 33: 563-567. [Crossref]

77. Cui G, Yuan A, Goll R, Olsen T, Husebekk A, et al. (2007) Distinct changes of dendritic cell number and IL-12 mRNA level in adjacent mucosa throughout the colorectal adenoma-carcinoma sequence. Cancer Immunol Immunother 56: 1993-2001. [Crossref]

78. Torre D, Giola M, Speranza F, Matteelli A, Basilico C, et al. (2001) Serum levels of interleukin-18 in patients with uncomplicated Plasmodium falciparum malaria. Eur Cytokine Netw 12: 361-364. [Crossref]

79. Gazzinelli RT, Eltoum I, Wynn TA, Sher A (1993) Acute cerebral toxoplasmosis is induced by in vivo neutralization of TNF-alpha and correlates with the down-regulated expression of inducible nitric oxide synthase and other markers of macrophage activation. J Immunol 151: 3672-3681. [Crossref]

80. Harmey JH, Dimitriadis E, Kay E, Redmond HP, Bouchier-Hayes D (1998) Regulation of macrophage production of vascular endothelial growth factor (VEGF) by hypoxia and transforming growth factor beta-1. Ann Surg Oncol 5: 271-278. [Crossref]

81. Löfstedt T, Fredlund E, Holmquist-Mengelbier L, Pietras A, Ovenberger M, et al (2007) Hypoxia inducible factor-2alpha in cancer. Cell Cycle 6: 919-926. [Crossref]

82. Salnikov AV, Roswall P, Sundberg C, Gardner H, Heldin NE, et al. (2005) Inhibition of TGF-beta modulates macrophages and vessel maturation in parallel to a lowering of interstitial fluid pressure in experimental carcinoma. Lab Invest 85: 512-521. [Crossref]

83. Poteryaeva ON, Polyakov LM, Korolenko TA, Zueva TV, Russkikh GS, et al. (2004) Effect of polysaccharides and human plasma lipoproteins on the secretion of cystatin C by peritoneal macrophages from normal and tumor bearing mice. Biochemistry (Mosc) 69: 295-298. [Crossref]

84. Braunschweiger PG, Basrur VS, Cameron D, Sharpe L, Santos O, et al. (1997) Modulation of cisPlatin cytotoxicity by interleukin-1 alpha and resident tumor macrophages. Biotherapy 10: 129-137. [Crossref]

85. Cao Y, Cao R, Hedlund EM (2008) R Regulation of tumor angiogenesis and metastasi by FGF and PDGF signaling pathways. J Mol Med (Berl) 86: 785-789. [Crossref]

86. Lee H, Baek S, Joe SJ, Pyo SN (2006) Modulation of IFN-gamma production by TNFalpha in macrophages from the tumor environment: significance as an angiogenic switch. Int Immunopharmacol 6: 71-78. [Crossref]

87. Mukherjee P, Ginardi AR, Madsen CS, Tinder TL, Jacobs F, et al. (2001) MUC1 
specific CTLs are non-functional within a pancreatic tumor microenvironment. Glycoconj J 18: 931-942. [Crossref]

88. Sieuwerts AM, Klijn JG, Henzen-Logmans SC, Foekens JA (1999) Cytokine-regulated urokinase-type-plasminogen-activator (uPA) production by human breast fibroblasts in vitro. Breast Cancer Res Treat 55: 9-20. [Crossref]

89. Tartour E, Fridman WH (1998) Cytokines and cancer. Int Rev Immunol 16: 683-704. [Crossref]

90. Prakash H, Klug F, Nadella V, Mazumdar V, Schmitz-Winnenthal H, et al. (2016) Low doses of gamma irradiation potentially modifies immunosuppressive tumor microenvironment by retuning tumor-associated macrophages: lesson from insulinoma. Carcinogenesis 37: 301-313. [Crossref]

91. Klug F, Prakash H, Huber PE, Seibel T, Bender N, et al. (2013) Low-dose irradiation programs macrophage differentiation to an iNOS $(+) / \mathrm{M} 1$ phenotype that orchestrates effective T cell immunotherapy. Cancer Cell 24: 589-602. [Crossref]

92. Lyamina SV, Kruglov SV, Vedenikin TY, Borodovitsyna OA, Suvorova IA, et al. (2012) Alternative reprogramming of M1/M2 phenotype of mouse peritoneal macrophages in vitro with interferon-gamma and interleukin-4. Bull Exp Biol Med 152: 548-551. [Crossref]

93. Lu T, Gabrilovich DI (2012) Molecular pathways: tumor-infiltrating myeloid cells and reactive oxygen species in regulation of tumor microenvironment. Clin Cancer Res 18: 4877-4882. [Crossref]

94. Gabrilovich DI, Ostrand-Rosenberg S, Bronte V (2012) Coordinated regulation of myeloid cells by tumours. Nat Rev Immunol 12: 253-268. [Crossref]

95. Chanmee T, Ontong P, Konno K, Itano N (2014) Tumor-associated macrophages as major players in the tumor microenvironment. Cancers (Basel) 6: 1670-1690. [Crossref]

96. Zeisberger SM, Odermatt B, Marty C, Zehnder-Fjällman AH, Ballmer-Hofer K, et al. (2006) Clodronate-liposome-mediated depletion of tumour-associated macrophages: a new and highly effective antiangiogenic therapy approach. Br J Cancer 95: 272-281. [Crossref]

97. Sessa A, Battini G, Meroni M, Pitingolo F, Righetti M, et al. (2005) Multifocal bilateral renal cell carcinoma and retinal angiomas in a patient with de novo von Hippel-Lindau disease: identification of a new germline mutation. J Nephrol 18: 209-212. [Crossref]

98. Sessa C, De Braud F, Perotti A, Bauer J, Curigliano G, et al. (2005) Trabectedin for women with ovarian carcinoma after treatment with platinum and taxanes fails. $J$ Clin Oncol 23: 1867-1874. [Crossref]

99. Park HC, Seong J, Tanaka M, Zeng ZC, Lim HY, et al. (2011) Multidisciplinary management of nonresectable hepatocellular carcinoma. Oncology 81: 134-140. [Crossref]

100. Lee IJ, Seong J (2011) Radiotherapeutic strategies in the management of hepatocellular carcinoma. Oncology 81: 123-133. [Crossref]

101. Shin SJ, Kim NK, Keum KC, Kim HG, Im JS, et al. (2010) Phase II study of preoperative chemoradiotherapy (CRT) with irinotecan plus S-1 in locally advanced rectal cancer. Radiother Oncol 95: 303-307. [Crossref]

102. Seol YM, Kwon BR, Song MK, Choi YJ, Shin HJ, et al. (2010) Measurement of tumor volume by PET to evaluate prognosis in patients with head and neck cancer treated by chemo-radiation therapy. Acta Oncol 49: 201-208. [Crossref]

103. Fujita T, Timme TL, Tabata K, Naruishi K, Kusaka N, et al. (2007) Cooperative effects of adenoviral vector-mediated interleukin 12 gene therapy with radiotherapy in a preclinical model of metastatic prostate cancer. Gene Ther 14: 227-236. [Crossref]

104. Hoegl S, Zwissler B, Eltzschig HK, Vohwinkel C (2016) Acute respiratory distress syndrome following cardiovascular surgery: current concepts and novel therapeutic approaches. Curr Opin Anaesthesiol 29: 94-100. [Crossref]

105. Kim JW, Ha KY, Molon JN, Kim YH (2013) Bone marrow-derived mesenchymal stem cell transplantation for chronic spinal cord injury in rats: comparative study between intralesional and intravenous transplantation. Spine (Phila Pa 1976) 38: E1065-E1074. [Crossref]

106. Broughton BR, Lim R, Arumugam TV, Drummond GR, Wallace EM, et al. (2013) Post-stroke inflammation and the potential efficacy of novel stem cell therapies: focus on amnion epithelial cells. Front Cell Neurosci 6: 66. [Crossref]

107. Boxman IL, Ruwhof C, Boerman OC, Löwik CW, Ponec M (1996) Role of fibroblasts in the regulation of proinflammatory interleukin IL-1, IL-6 and IL-8 levels induced by keratinocyte-derived IL-1. Arch Dermatol Res 288: 391-398. [Crossref]

108. Voloshin T, Alishekevitz D, Kaneti L, Miller V, Isakov E, et al. (2015) Blocking
IL1beta Pathway Following Paclitaxel Chemotherapy Slightly Inhibits Primary Tumor Growth but Promotes Spontaneous Metastasis. Mol Cancer Ther 14: 1385-1394.

109. Agostinis P, Berg K, Cengel KA, Foster TH, Girotti AW, et al. (2011) Photodynamic therapy of cancer: an update. CA Cancer J Clin 61: 250-281. [Crossref]

110. Li J, Shen KN, Huang WR, Li LH, Chen H, et al. (2014) Autologous stem cel transplant can overcome poor prognosis in patients with multiple myeloma with extramedullary plasmacytoma. Leuk Lymphoma 55: 1687-1690. [Crossref]

111. Liu J, Li J, Huang B, Zheng D, Chen M, et al. (2013) Determining the optimal time for bortezomib-based induction chemotherapy followed by autologous hematopoietic stem cell transplant in the treatment of multiple myeloma. Chin J Cancer Res 25 : 166-174. [Crossref]

112. Han TT, Xu LP, Liu DH, Liu KY, Zhang XH, et al. (2013) [Prevalence of EBV infection in patients with allogeneic hematopoietic stem cell transplantation] Zhonghua Xue Ye Xue Za Zhi 34: 651-654. [Crossref]

113. Sulyok I, Fleischmann E, Stift A, Roth G, Lebherz-Eichinger D, et al. (2012) Effect of preoperative fever-range whole-body hyperthermia on immunological markers in patients undergoing colorectal cancer surgery. Br J Anaesth 109: 754-761. [Crossref]

114. Maluta S, Romano M, Dall'oglio S, Genna M, Oliani C, et al. (2010) Regional hyperthermia added to intensified preoperative chemo-radiation in locally advanced adenocarcinoma of middle and lower rectum. Int J Hyperthermia 26: 108-117. [Crossref]

115. Szasz A (2007) Hyperthermia, a modality in the wings. J Cancer Res Ther 3: 56-66. [Crossref]

116. Fiorentini G, Szasz A (2006) Hyperthermia today: electric energy, a new opportunity in cancer treatment. $J$ Cancer Res Ther 2: 41-46. [Crossref]

117. van der Zee J (2002) Heating the patient: a promising approach? Ann Oncol 13: 11731184. [Crossref]

118. Ridner SH, Poage-Hooper E, Kanar C, Doersam JK, Bond SM, et al. (2013) A pilo randomized trial evaluating low-level laser therapy as an alternative treatment to manual lymphatic drainage for breast cancer-related lymphedema. Oncol Nurs Forum 40: 383-393. [Crossref]

119. Ben-Zvi T, Hueber PA, Abdollah F, Liberman D, Bhojani N, et al. (2013) Short term outcomes of GreenLight vapor incision technique (VIT) of the prostate: comparison of outcomes to standard GreenLight 120W HPS vaporization in prostate volumes greater than 80 cc. Can J Urol 20: 6633-6639. [Crossref]

120. Ribas A, Chesney JA, Gordon MS, Abernethy AP, Logan TF, et al. (2012) Safety profile and pharmacokinetic analyses of the anti-CTLA4 antibody tremelimumab administered as a one hour infusion. J Transl Med 10: 236. [Crossref]

121. Hamid O, Robert C, Daud A, Hodi FS, Hwu WJ, et al. (2013) Safety and tumor responses with lambrolizumab (anti-PD-1) in melanoma. $N$ Engl J Med 369: 134-144. [Crossref]

122. Hamid O, Carvajal RD (2013) Anti-programmed death-1 and anti-programmed deathligand 1 antibodies in cancer therapy. Expert Opin Biol Ther 13: 847-861. [Crossref]

123. Armand P, Nagler A, Weller EA, Devine SM, Avigan DE, et al. (2013) Disabling immune tolerance by programmed death-1 blockade with pidilizumab after autologous hematopoietic stem-cell transplantation for diffuse large B-cell lymphoma: results of an international phase II trial. J Clin Oncol 31: 4199-4206.

124. Goswami A, Shah BA, Kumar A, Rizvi MA, Kumar S, et al. (2014) Antiproliferative potential of a novel parthenin analog P16 as evident by apoptosis accompanied by down-regulation of PI3K/AKT and ERK pathways in human acute lymphoblastic leukemia MOLT-4 cells. Chem Biol Interact 222C: 60-67. [Crossref]

125. Soria JC, Baselga J, Hanna N, Laurie SA, Bahleda R, et al. (2013) Phase I-IIa study of BMS-690514, an EGFR, HER-2 and -4 and VEGFR-1 to -3 oral tyrosine kinase inhibitor, in patients with advanced or metastatic solid tumours. Eur J Cancer 49: 1815-1824. [Crossref]

126. Brahmer JR, Tykodi SS, Chow LQ, Hwu WJ, Topalian SL, et al. (2012) Safety and activity of anti-PD-L1 antibody in patients with advanced cancer. $N$ Engl J Med 366 : 2455-2465. [Crossref]

127. Topalian SL, Drake CG, Pardoll DM (2012) Targeting the PD-1/B7-H1(PD-L1) pathway to activate anti-tumor immunity. Curr Opin Immunol 24: 207-212. [Crossref]

128. Britten CM, Singh-Jasuja H, Flamion B, Hoos A, Huber C, et al. (2013) The regulatory landscape for actively personalized cancer immunotherapies. Nat Biotechnol 31: 880882. [Crossref] 
129. Mkrtichyan M, Chong N, Abu Eid R, Wallecha A, Singh R, et al. (2013) Anti-PD-1 antibody significantly increases therapeutic efficacy of Listeria monocytogenes (Lm)LLO immunotherapy. J Immunother Cancer 1: 15. [Crossref]

130. Löb S, Königsrainer A, Rammensee HG, Opelz G, Terness P (2009) Inhibitors of indoleamine-2,3-dioxygenase for cancer therapy: can we see the wood for the trees? Nat Rev Cancer 9: 445-452. [Crossref]

131. Wainwright DA, Dey M, Chang A, Lesniak MS (2013) Targeting Tregs in Malignant Brain Cancer: Overcoming IDO. Front Immunol 4: 116. [Crossref]

132. Smith C, Chang MY, Parker KH, Beury DW, DuHadaway JB, et al. (2012) IDO is a nodal pathogenic driver of lung cancer and metastasis development. Cancer Discov 2: 722-735. [Crossref]

133. Moon YW, Hajjar J, Hwu P, Naing A (2015) Targeting the indoleamine 2,3-dioxygenase pathway in cancer. J Immunother Cancer 3: 51. [Crossref]

134. Eini H, Frishman V, Yulzari R, Kachko L, Lewis EC, et al. (2015) Caffeine promotes anti-tumor immune response during tumor initiation: Involvement of the adenosine A2A receptor. Biochem Pharmacol 98: 110-118. [Crossref]

135. Leone RD, Lo YC, Powell JD (2015) A2aR antagonists: Next generation checkpoint blockade for cancer immunotherapy. Comput Struct Biotechnol J 13: 265-272. [Crossref]

136. Cekic C, Day YJ, Sag D, Linden J (2014) Myeloid expression of adenosine A2A receptor suppresses $\mathrm{T}$ and $\mathrm{NK}$ cell responses in the solid tumor microenvironment. Cancer Res 74: 7250-7259. [Crossref]

137. Loi S, Pommey S, Haibe-Kains B, Beavis PA, Darcy PK, et al. (2013) CD73 promotes anthracycline resistance and poor prognosis in triple negative breast cancer. Proc Natl Acad Sci U S A 110: 11091-11096. [Crossref]

138. Ngiow SF, Teng MW, Smyth MJ (2011) Prospects for TIM3-Targeted Antitumor Immunotherapy. Cancer Res 71: 6567-6571. [Crossref]

139. Ngiow SF, von Scheidt B, Akiba H, Yagita H, Teng MW, et al. (2011) Anti-TIM3 antibody promotes $\mathrm{T}$ cell IFN-gamma-mediated antitumor immunity and suppresses established tumors. Cancer Res 71: 3540-3551. [Crossref]

140. Sakuishi K, Apetoh L, Sullivan JM, Blazar BR, Kuchroo VK, et al. (2010) Targeting Tim-3 and PD-1 pathways to reverse T cell exhaustion and restore anti-tumor immunity. J Exp Med 207: 2187-2194. [Crossref]

141. Woo HN, Chung HK, Ju EJ, Jung J, Kang HW, et al. (2012) Preclinical evaluation of injectable sirolimus formulated with polymeric nanoparticle for cancer therapy. Int $J$ Nanomedicine 7: 2197-2208. [Crossref]

142. Jing L, Shi J, Fan D, Li Y, Liu R, et al. (2015) (177)Lu-Labeled Cerasomes Encapsulating Indocyanine Green for Cancer Theranostics. ACS Appl Mater Interfaces 7: 22095-22105. [Crossref]

143. Carrega P, Morandi B, Costa R, Frumento G, Forte G, et al. (2008) Natural killer cells infiltrating human nonsmall-cell lung cancer are enriched in CD56 bright CD16(-) cells and display an impaired capability to kill tumor cells. Cancer 112: 863-875. [Crossref]

144. Björklund AT, Schaffer M, Fauriat C, Ringdén O, Remberger M, et al. (2010) NK cells expressing inhibitory KIR for non-self-ligands remain tolerant in HLA-matched sibling stem cell transplantation. Blood 115: 2686-2694. [Crossref]

Copyright: (2016 Nadella V. This is an open-access article distributed under the terms of the Creative Commons Attribution License, which permits unrestricted use, distribution, and reproduction in any medium, provided the original author and source are credited. 